\title{
Publisher Correction: Activation of G-protein-gated inwardly rectifying potassium (Kir3/GirK) channels rescues hippocampal functions in a mouse model of early amyloid- $\beta$ pathology
}

Irene Sánchez-Rodríguez $\mathbb{D}$, Sara Temprano-Carazo $\mathbb{D}$, Alberto Nájera $\mathbb{D}$, Souhail Djebari $\mathbb{D}_{\text {, }}$ JavierYajeya, Agnès Gruart, José M. Delgado-García, Lydia Jiménez-Díaz (D) \& Juan D. Navarro-López

Correction to: Scientific Reports https://doi.org/10.1038/s41598-017-15306-8, published online 07 November 2017

The original version of this Article contained an error in Affiliation 1, which was incorrectly given as 'University of Castilla-La Mancha, NeuroPhysiology \& Behavior Laboratory, Centro Regional de Investigaciones Biomédicas, Albacete, Spain'. The correct affiliation is listed below:

University of Castilla-La Mancha, NeuroPhysiology \& Behavior Laboratory, Centro Regional de Investigaciones Biomédicas, School of Medicine of Ciudad Real, Ciudad Real, Spain

This error has now been corrected in the HTML and PDF versions of the Article.

(c) (i) Open Access This article is licensed under a Creative Commons Attribution 4.0 International (c) License, which permits use, sharing, adaptation, distribution and reproduction in any medium or format, as long as you give appropriate credit to the original author(s) and the source, provide a link to the Creative Commons license, and indicate if changes were made. The images or other third party material in this article are included in the article's Creative Commons license, unless indicated otherwise in a credit line to the material. If material is not included in the article's Creative Commons license and your intended use is not permitted by statutory regulation or exceeds the permitted use, you will need to obtain permission directly from the copyright holder. To view a copy of this license, visit http://creativecommons.org/licenses/by/4.0/.

(C) The Author(s) 2020 